\title{
Transmission System and Rural Electrification Scheme in Nigeria: Issues, Challenges, Constraints and Way forward
}

\author{
${ }^{1 *}$ Akpojedje, F. O., \& ${ }^{2}$ Mormah, E. C.
}

${ }^{1}$ Department of Electrical/Electronic Engineering Technology, National Institute of Construction Technology and Management, Uromi, Nigeria; '2Department of Electrical/Electronic Engineering, Delta State Polytechnic, Ogwashi Uku, Nigeria.

*Corresponding author's e-mail: francetech007@yahoo.com

\begin{abstract}
This paper $\mathrm{x}$-rayed the transmission system and rural electrification scheme in Nigeria. The electric power transmission network and rural electrification scheme were critically reviewed in terms of issues, challenges, constraints, roles and current state of the power systems to identify their areas of strength and shortcomings in the Nigeria power sector. The paper further proposes the way forward to enhance the performance of the Nigeria's electric power transmission system and rural electrification scheme.
\end{abstract}

Received 15 August 2019; Revised 15 November 2019; Accepted 30 November 2019; Available online 2 December 2019.

\begin{tabular}{l} 
Keywords \\
\hline Power system \\
infrastructure; \\
Rural \\
electrification \\
scheme; \\
Transmission \\
Company of \\
Nigeria; \\
Transmission \\
system.
\end{tabular}

Copyright @ 2019 The Authors. This is an open access article under the CC BY-NC-ND license (http://creativecommons.org/licenses/by-nc-nd/4.0/)

\section{Introduction}

Power systems is one of the most complex system ever built by man. Hence, due to its complexity and tremendous power requirements in recent times, we must constantly be concerned with the efficient operation of our electric power systems, especially the transmission network and its associated system (Patrick \& Fardo, 2009). Transmission system being the major link between the generating station and distribution network, it evacuates the bulk power generated from the generating station to the consumers through the distribution network. Consequently, transmission system is the strong link that play a vital role if the power generated is to be evacuated or transported to the point of consumption. Therefore, the importance of transmission system in the power value chain of the Nigeria electricity industry cannot be overemphasised.

The electric power is an essential commodity to human endeavour because it interfaces nearly all human activities. According to Ajenikoko et al. (2018) opined that electric power supply is one of the basic infrastructural requirements for industrialisation, productivity and growth in any economy as well as improvement in the quality of life. Hence, a reliable power system (stable electric power supply) is a key and the sine qua non to a sustainable and rapid development of a nation. In other words, electric power drives the economy of a nation and its reliability sustains her developmental growth (Akpojedje et al., 2016). According to Onyi-Ogelle (2016) who stated that power is indeed an indispensable component of economic growth and development; as increase in supply of stable electricity enhances national productivity and economic development. Technically, there is a strong correlation between the standard of living and the available power supply for consumption in a nation.

Citation: Akpojedje, F. O., \& Mormah, E. C. (2019). Transmission system and rural electrification scheme in Nigeria: issues, challenges, constraints and way forward. Journal of Advances in Science and Engineering, 2(2): 9-28. DOI: https://doi.org/10.37121/jase.v2i2.60 
Historically, the Nigeria power supply is dated back to 1896 when electricity was first produced in Lagos, fifteen years after its introduction in England (Niger Power Review, 1985). "The total capacity of power generation was $60 \mathrm{~kW}$. In other words, the maximum power demand in 1896 was less than 60kW. In 1946 the Nigerian government electricity undertaking was established under the jurisdiction of Public Works department (PWD) to take over the responsibility of electricity supply in Lagos state. In 1959, the Electricity Corporation of Nigeria (ECN) was formed as a central body; other bodies like Nigerian Electricity Supply Company (NESCO) and Niger Dams Authority (NDA) were also formed. The NDA was established by act of parliament to produce electricity and sell to ECN which they distribute and sell at utility voltages. In April 1972, the operations of ECN and NDA (Niger Dams Authority) were merged in a new organisation known as the National Electricity Power Authority (NEPA)" (Okoro \& Chikuni, 2007). The Nigeria rural electrification actually started in 1981 with the introduction of the National Rural Electrification Programme (NREP), which was being executed by the then National Electricity Power Authority (NEPA) on behalf of the federal government of Nigeria. The aim of NREP was to connect the headquarters of all the 774 Local Government Areas (LGAs) to the national grid system (Ohiare, 2014). The NREP succeeded in connecting 600 of the LGAs to the national grid. However, local distribution network within the LGAs connected has not expanded beyond the LGAs headquarters and its immediate environs, to other interior villages and rural communities due to rural electrification issues and challenges. As at today, only $12.5 \%$ of Nigerians population have access to power supply out of one hundred and eighty (180) million people in Nigeria as estimated today (PWC, 2016).

Since inception of NEPA, the authority expands annually in order to meet the everincreasing power demand (Rural Electrification Agency, 2014). Unfortunately, the majority of Nigerians have no access to electricity and the supply to those that have access is not regular. It is on this backdrop that federal government has embarked on aggressive power sector reforms with the intention of resuscitating NEPA and making it more efficient, effective and responsive to the yearnings of the teeming populace (Okoro \& Chikuni, 2007).

Before the unbundling of the Nigeria power sector, the transmission system of Nigeria was controlled solely by the defunct NEPA which was later changed to Power Holding Company of Nigeria (PHCN). Under the defunct NEPA system, Nigeria's power sector is made up of three (3) major subsectors namely: Generation, Transmission and Distribution system and the power sectors have been operating for many years under the defunct NEPA till 2005 (Isola, 2012). After the unbundling of the Nigeria power sector, following the Electricity Power Sector Reform (EPSR) Acts of 2005, NEPA was replaced by Power Holding Company of Nigeria (PHCN) (Ajenikoko et al., 2018). However, there were no remarkable improvements in electric power supply to consumers under PHCN even when the Nigeria Government continue to inject billions of naira into the sector annually (Edet \& Boniface, 2016; Isgogo, 2013; Iwuamadi et al., 2014). On $1^{\text {st }}$ of November, 2013 the federal government handed over the PHCN to eighteen successor companies, which is made up of six (6) generation companies, one electricity transmission company and eleven distribution companies which mark the end of PHCN (Ajenikoko et al., 2018). As at today, we can categorise Nigeria power sector into three companies: Generation Companies (GenCos), which are Egbin Electricity Company (EEGC), and those at Sapele, Ughelli, Afam, Shiroro and Kainji. There are also some new Independent Power Producers (IPPs) under the aegis of the Niger-Delta Power Holding Company (NDPHC) (Kalu, 2018).

The eleven Distribution Companies (DisCos), which are the Electricity Distribution Companies of Abuja, Eko, Enugu, Ibadan, Ikeja, Jos, Kaduna, Port-Harcourt and Yola respectively. The coverage of DisCos areas is illustrated in Figure 1 (Ugwoke et al., 2016; Yusuf, 2014). 


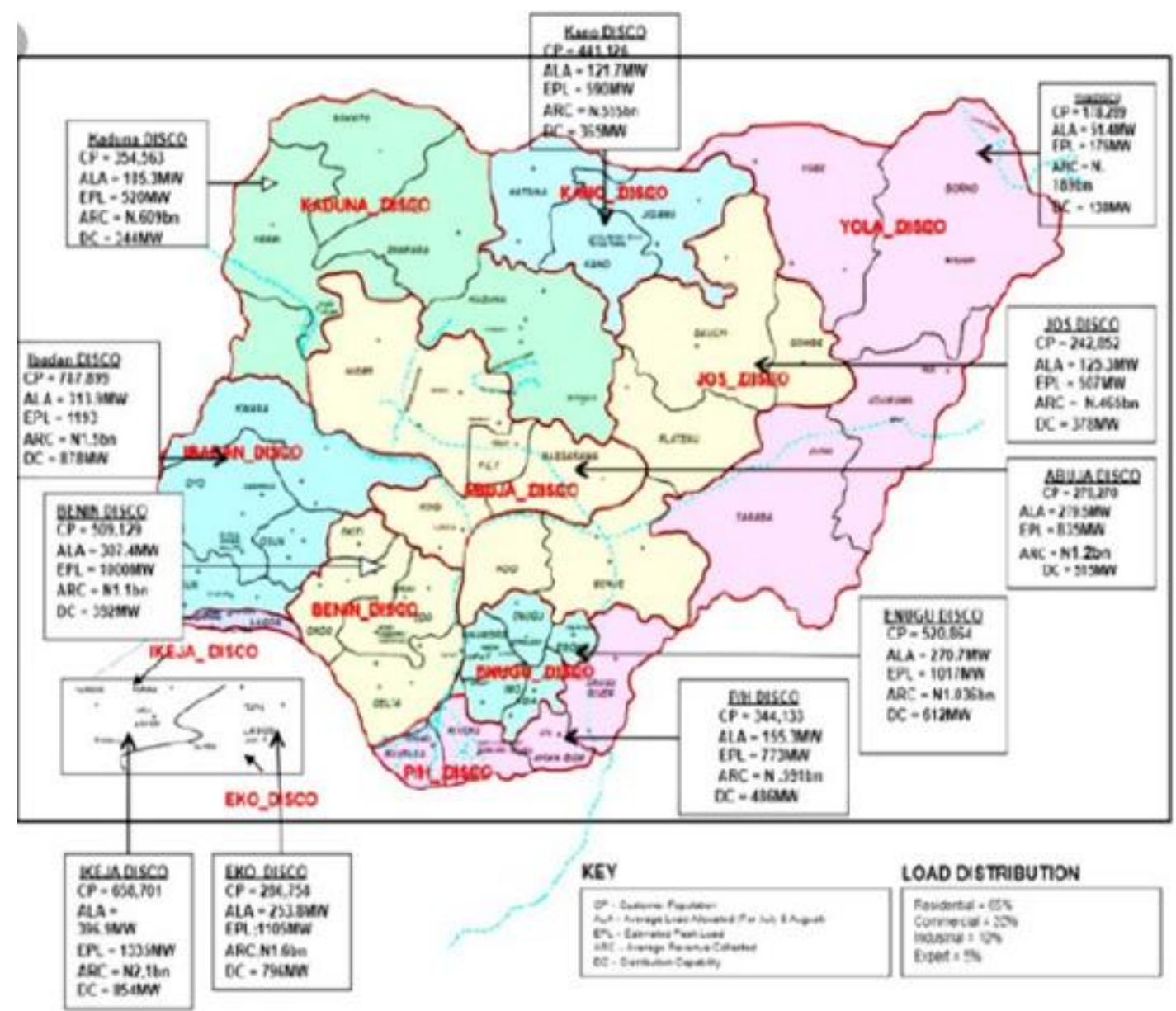

Figure 1. Nigeria Distribution Companies Coverage Area (Ugwoke et al., 2016)

The Transmission Company (TransCo) in Nigeria, which is called the Transmission Company of Nigeria (TCN) is a successor company of the then Power Holding Company of Nigeria (PHCN); following the unbundling of the power sector, and is currently being managed by a management contractor, Manitoba Hydro International (Canada) which is responsible for revamping TCN to achieve and provide stable transmission of electric power without system failure (Onochie et al., 2015; Ogunleye, 2016; Ologundudu, 2015). The TCN is made up of two major departments: System Operator (SO) and Market Operator (MO) (Onakoya, 2013). "The Market Operator is a department under TCN charged with the responsibility of administering the wholesale electricity market, promoting efficiency and where possible competition. While the System Operator focused on system planning, administration and grid disciplines" (Oyedepo, 2012; Rapu et al., 2014; Ugwoke et al., 2016; Wara et al., 2009).

The Nigeria transmission lines require constant balance of power supply, demand and wheeling capacity. The transmission system is operated for two main primary objectives: the reliability and the economy of the physical system. Thus, from an operational perspective, it is the transmission system operators that are responsible for achieving an efficient, economic and reliable power supply. Currently, the length of Nigeria electricity transmission system is made up of about $5,528.8 \mathrm{~km}$ of $330 \mathrm{kV}$ lines and $6,801.49 \mathrm{~km}$ of $132 \mathrm{kV}$ lines (Onochie et al., 2015). The transmission network operators majorly focus on system planning, administration and discipline. But with the above mentioned, there are various issues, challenges and constraints facing the Nigeria transmission network and the rural electrification scheme today. 
This paper is organised as follows: section 2 deal with issues, challenges and constraints of Nigeria power transmission network; section 3 the current state of the Nigeria transmission network infrastructure; section 4 assessment of Nigeria rural electrification scheme; section 5 issues and challenges of Nigeria rural electrification scheme; section 6 the way forward; and section 7 conclusion.

\section{Issues, Challenges and Constraints of the Nigeria Power Transmission Network}

The Nigeria transmission network is made up of about $5,528.8 \mathrm{~km}$ of $330 \mathrm{kV}$ and $6,801.49 \mathrm{~km}$ of $132 \mathrm{kV}$ transmission lines with $986.5 \mathrm{~km}$ of $330 \mathrm{kV}$ and $705.3 \mathrm{~km}$ of $132 \mathrm{kV}$ lines under construction (Onochie et al., 2015; Labo, 2010). Despite the aforementioned, there are different issues, challenges and constraints facing the Nigeria power transmission network today. The complexity of the Nigeria Grid Structure (NGS) arises from the fact that the Nigeria transmission lines span a lengthy distance to evacuate the power generated from generation points to consumers. This section of the paper will deal with the issues, challenges and constraints facing the TCN in two major ways: technical issues, challenges and constraints; and the non-technical issues, challenges and constraints.

\subsection{Technical Issues, Challenges and Constraints}

The effect of technical issues, challenges and constraints on the Nigeria transmission system have far negative impact on system which has hampered the efficiency of evacuating power generated in Nigeria. They increase both the cost of production of energy as well as delivery cost in the system. Some of the major technical issues, challenges and constraints are highlighted as follows (Ekeh, 2003):

(a) Lengthy Transmission Lines: The Nigeria evacuation (transmission) network is characterized with very lengthy transmission lines and feeders which make voltage control difficult. The Nigeria Grid Structure is geographically widespread and some of these lines include: Kainji - Birnin Kebbi (310km), Jebba - Shirro (244km), Oshogbo - Ikeja West $(235 \mathrm{~km})$, Jos - Gombe $(265 \mathrm{~km})$. The lengthy transmission network of Nigeria has reduce the maximum power transfer capability on the lines, thereby reducing the margin between the planned power transfer and the maximum limit at which the lines are susceptible to transient and dynamic instability; and the restoration of power supply to the National Grid after major system disturbances is often delayed because of the necessity to ensure that adequate reactors are in the circuit and enough units have been synchronized to compensate the reactive MVArs generated by the lengthy transmission lines before switching.

(b) Few Mesh System: One of the major determinants of a power system's reliability index is the available numbers of substitute routes of power flow from a power station of the grid to another. The structure of the Nigeria National Grid System is weak due to the existence of several single lengthy radial transportation lines with very few meshes or duplicated lines, thus constituting a single risk.

(c) Dielectric Losses: These are losses that result from the heating effect of the dielectric material between the conductors. The heat produced is dissipated in the surrounding medium thereby making system to heat up and increase losses in the system.

(d) Frequent System Collapse: Frequent system collapse in the Nigerian Grid (NG) is one of the major cause of unreliability in the transmission system of the Nigeria power sector. Over the past decades, there were series of collapses in the Nigeria grid due to voltage instability due to overloading in the grid and lengthen transmission lines which is responsible for high power losses in the grid. According to the then President Jonathans' Speech, which was capture by Samuel et al. (2014) said that the Nigerian National Grid (NNG) is highly stressed and weak, this makes it prone to voltage instability and eventually voltage collapse." Voltage collapse is one of the major causes of system collapse. It is on record that despite the huge capital and human 
resources investment in the Nigeria power sector, the power sector still suffered two hundred and six (206) times grid collapses in nine (9) years (Samuel \& Sunday, 2019). The breakdown of the collapses of the two hundred and six (206) in nine (9) years between 2010 and 2019 is indicated as follows:

(i) The Nigerian grid collapse one hundred and nine (109) times between 2010 and 2013 which led to power cut in major part of the country.

(ii) "The Nigeria as a country went into total darkness in twenty-two (22) times and recorded twenty (20) partial outages in 2010. The Nigeria grid also had thirteen (13) incidents of total collapse and six (6) partial incidents in 2011. By 2012, there were sixteen (16) total collapse and eight (8) partial ones. Additionally, in 2013 there were twenty-two (22) total power grid collapse while partial trappings occurred twice (2). In the year 2014, it recorded nine (9) total and four (4) partial collapses. It became heightened in 2016 when the grid tripped for twenty-two (22) times and went off partially six (6) times. Surveys revealed that in 2017, there were fifteen (15) times total and nine (9) partial collapses were recorded while in 2018, twelve (12) total grid collapse. Furthermore, in 2019, there were nine (9) total collapses that have been recorded; four (4) which occurred in January while five (5) others are spread across February, April, May, June and August, 2019". Averagely, the Nigeria electricity grid collapse approximately twenty-three (23) times every year. But according to Samuel et al. (2014) opined that the Nigerian National Grid (NNG) experiences on an average of thirty-five (35) system collapses every year over the past ten (10) years.

(e) Induction and Radiation Losses: These losses are produced by the electromagnetic fields surrounding the transmission line conductor links another line or metallic objects where by current is induced in the object. As a result, power is dissipated in the object and losses occur.

(f) Transformer Losses: The largest technical issue in the power transmission system in Nigeria is the transformer losses which contribute to the inefficiency of the power transmission network. The transformer losses are of two types. These include the winding losses (due to internal impedance of the transformer coils) and core losses.

(g) Lightning: This is the second transmission technical and major issue faced by TCN. The transmission lines are built with a grounded shield wire placed along the top of the pole, above the conductors. Typically, the shield wire is bonded to ground at each transmission structure. This protects the transmission line from lightning but adequate lightning arrestor fixed on the line will arrest the ugly incident of lightning strike.

(h) Fallen Lines: The transmission lines fall as a result of being hit by vehicle and such lines are not fixed or repaired on time. This often causes high downtime period in the system thereby affecting the system reliability and availability of power to Nigerians.

(i) Inadequate Spare Parts: The unavailability of spare parts, poor technical staff and training program affect maintenance of transmission lines. These are necessary for the efficient performance of workers and the system.

(j) Lack of Modern Technology: There is serious lack of required modern technology for communication and monitoring in the system. The absence of modern technology is also one of the major issues faced by the Nigeria power transmission system. This has reduced the system to analogue stage where reliability is highly hindered.

(k) Ferrant Effect: This effect is caused as a result of longer or medium transmission line. The Long lines have considerable capacitance and hence draws leading current from the generating sending- end when unloaded. This makes the receiving-end voltage greater than sending-end voltage under no-load condition. The use of reactor is one of the possible solution to this ugly occurrence.

(I) Corona Effect: This is another technical issue facing the transmission system and is caused by local ionisation of the air around the conductors of high voltage lines. In 
order to minimise corona, we must reduce the electric field (V/M) around the conductors, either by increasing their diameter or by arranging them in set of two, three or more bundled conductors per phase. This effect has hampered the efficient performance of the power transmission system as well.

(m) Thermal and Current Constraints of the Transmission Network: The thermal and current constraints of the transmission line are one of the major limitations of the network. The thermal limitations are most common constraint that limit the capability of the transmission line, cables or transformers to evacuate maximum power (energy) to the consumers (Ogbogu \& Anaemeje, 2011). "The power handling ability of a line is limited by the thermal loading limit and the stability limit. The increase in the conductor temperature, due to the real power loss, stretches the conductors. This result to increase in sag of the transmission line" (Ogbogu \& Anaemeje, 2011).

(n) Voltage Constraints of the Transmission Network: The voltage of the transmission line is regarded as the measure of the electromotive force needed to maintain the flow of electricity in a transmission system. "Voltage fluctuations can occur due to variation in electricity demand and failures on the transmission lines. Constraints on the maximum voltage levels are set by the design of the transmission line. If the maximum voltage level is exceeded, then short circuit may occur, leading to abnormal power flow in the network (Ogbogu \& Anaemeje, 2011).

(o) Inappropriate Transmission System: The Nigeria electricity transmission network is spread over the entire $923,768 \mathrm{~km}$ areas that make up Nigeria but the transmission substations are sited centrally and the transmission lines emanated from the transmission substations. The size of the country is large, hence necessitated the transmission lines to run across cities in several kilometres, "sometimes stretching over swamp, wide rivers and thick forest, all which constitute hidden and real hazards that interrupt the smooth transportation of energy to consumers (Diji, 2014). Consequently, these increase the power losses on the transmission network.

(p) Weak Transmission Network: The transmission network of Nigeria presently is considered to be weak because of its capacity currently to "transmit" maximum power of about 5400MW (PWC, 2016) and it is technically weak, thus very sensitive to major disturbances (Sambo et al., 2010).

(q) Overloaded Transformers in the Transmission Network: Most times the transformers deployed at the transmission level are overloaded in most service areas. This is as a result of limited network in various geopolitical/geographical zones in the country. This is the case of Transmission Company of Nigeria (TCN), Sapele Road, Benin Branch, where two (2) 60MVA power transformers pack-up simultaneously as a result of overloading overtime. According to Akpojedje et al. (2016) "the Nigeria transmission transformers deployed are overloaded due to under rated or failure to upgrade the existing power transmission transformers during expansion of loads which resulted to limitations of optimal loading of the system." This constant overloading has caused the overheating of the system which led to insulation failure and eventually the machines gave way overtime. This resulted to blackout in major parts of Benin City and Its environs that eventually resulted to maximum loadshedding currently.

(r) High Transmission Losses: Basically, losses in electrical transmission lines can be identified as losses caused by the internal factors. These are the $I^{2} R$ losses that are inherent in all conductors because of the finite resistance of the conductors. In alternating current transmission lines, the line losses are higher due to skin effect (Akpojedje et al., 2016). These losses occur as a result of current flow through the resistive materials (conductors) and the magnetizing energy in the coils of transformers (Anumaka, 2012). Transmission line losses are one of the major technical issues faced by the TCN. According to Anumaka (2012), the transmission and distribution losses of Nigeria power sector have a large proportion-whopping of 
$40 \%$. Also, according to Onyi-Ogelle (2016) stated that the state of the grid system is characterised by frequent overloading, system collapses with $T$ (transmission) and D (distribution) losses of up to $40 \%$. The lengthy distance covered by Nigeria transmission lines also attribute to these high losses witness in the transmission network today. The Nigeria power sector has about thirteen (13) gigawatts (GW) of electricity generating capacity, out of which only about $25 \%$ is available and operational due to gas constraints (PWC, 2016). This meagre percentage amount generated due to various constraints is still being wasted when transported or evacuated through the transmission lines. It is on record that $7.4 \%$ of the $25 \%$ of power generated is lost across the transmission network due to various technical factors which naturally can be minimised; but due to the sub-optimal operation in which the Nigeria transmission network operate today with ageing and outdated skilled personnel, high losses are still being experienced. This is clearly shown on the transmission section of the Nigeria power sector energy flow in megawatts (MW) in Figure 2.

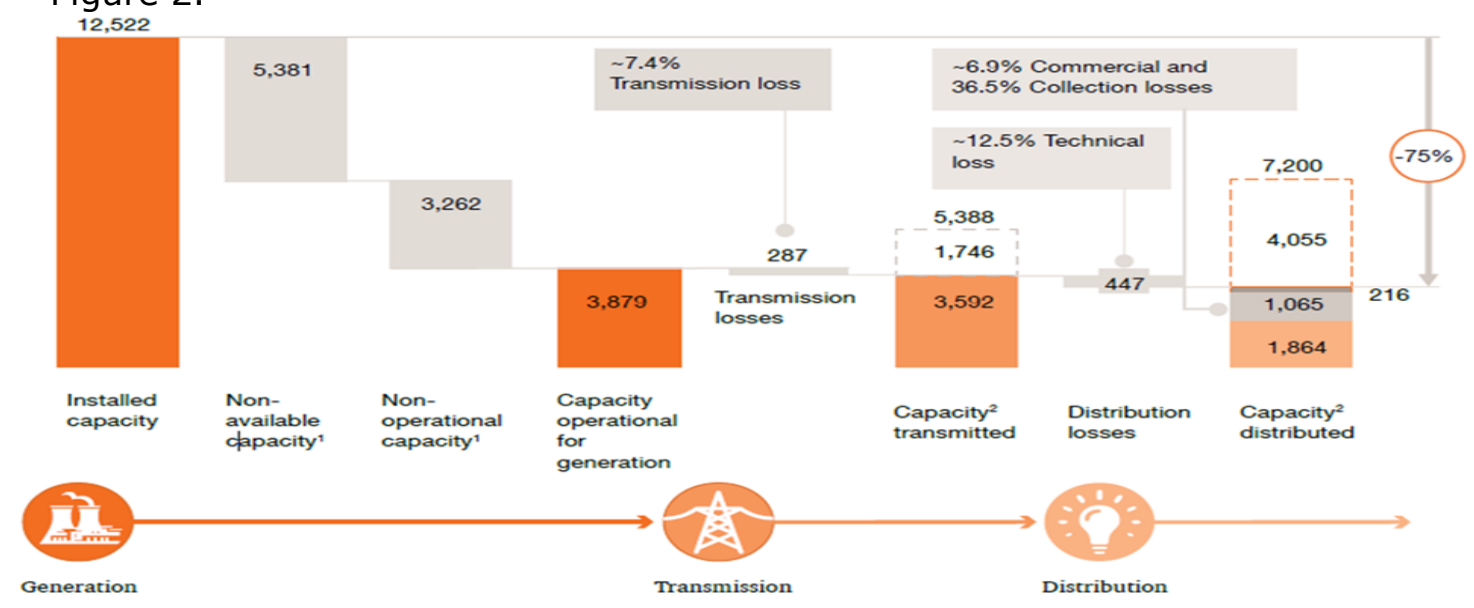

Figure 2. Nigeria Power Sector Energy Flow in Mega Watt (PWC, 2016)

\subsection{Non- Technical Issues, Challenges and Constraints}

The impact of non-technical issues, challenges and constraints on transmission lines have far negative effects as well. They increase both the cost of production of energy as well as delivery cost as earlier mentioned. Therefore, more cost for energy production due to non-technical issues in the transmission system. The major non-technical issues, challenges and constraints are highlighted as follows:

(a) Vandalisation: This is a societal problem that has been increasing the cost of transportation of electric power by billions of naira (Ekeh, 2003). Vandalisation of transmission equipment by unscrupulous individuals for selfish gains has become a recurrent decimal in the Nigerian power system (Onohaebi, 2009). It is man-made and can only be reversed by the people who engaged in it. The items like tower member, bolts and nuts, sky wire, counter pose wire, conductors, lightning arrestors, spindles and insulators are not spared by the vandals. According to the oxford advance learners Dictionary, vandalisation is defined as "wilful destruction or damage of public property." Vandals according to the same dictionary are "persons who wilfully destroy or damage works of art, public and private property, beauties of nature," including electric utility installation and facilities. Vandalisation of utility facilities is a crime worse than arm robbery. The arm robbers target individuals while the vandals of electric transmission lines are on the entire nation. Another reason we are convinced that vandalisation is worse than arm robbery is that most hospitals rely heavily on the power transmission for babies at birth (delivery), and to operate their medical equipment. Imagine that such hospitals are treating various patients, ranging from 
delivery of babies by various kinds of surgical operations, when these vandals strike most of the hospitals will come out with their patients dead (Ekeh, 2003).

(b) Loss of Man-Hour: The loss of man-hour resulted because the man-hour that would have been used in improving the transmission system is now being directed towards restoring the vandalised power transmission equipment or facilities (Ekeh, 2003).

(c) Loss of Revenue: This is one issue faced by the power transmission system as a result of technical and non-technical issue. The high losses in the power transmission line, if translated to money, high revenue is being wasted and the vandalized transmission facilities in the power transmission system lead to black-out in some part of the Nation (Ekeh, 2003). As long as the electric power transmission is non-functional, there will be no revenue for the power transmission company. Hence, vandalised power transmission facilities are thrown out of operation. Consequently, no revenue will be generated from the affected power transmission section of the nation.

(d) Loss of Funds: Each time vandals strike on electric power transmission line facilities; additional fund is wasted on restoring such transmission installations. The wasted funds in some cases would have been channelled to other projects such as transmission system improvement, reinforcement, and rehabilitation of broken poles and conductors (Ekeh, 2003).

(e) Lack of Modern Equipment: In Nigeria today, the power transmission network is faced with the usage of obsolete equipment. The equipment that were used to build the transmission network long ago are still in service as at today. This old equipment usage has been translated to frequent occurrence of fault in the network which has led to the epileptic nature of network. Also, "ageing and long usage of machines always reduce their efficiency. This means that more losses occur than the necessary to transport the same amount of power to consumers" when the machines are new.

(f) Policy on Engineering Infrastructure: The Nigeria policies on engineering infrastructure is very weak and unstable as at today. This is due to lack of local factory in the system which has become seriously difficult for the nation to support the industry with locally manufactured spare parts and policies somersault by every government that comes on board. Awosope (2014) is of the view that the establishment of the National Agency for Science and Engineering Infrastructure (NASENI) and operation of Ajaokuta Steel Rolling Mill would have been able to assist in the manufacturing of some of this electrical equipment. But this is not possible especially because there is no policy framework in this regard as at today that will support the manufacturing of the machines and their peripheries. And the government of Nigeria has not entered into any franchise with the manufacturers of these equipment (Odiah, 2011). The above situation mentioned can be related to the two (2) 60MVA power transformers that pack-up simultaneously at the Benin transmission station, Sapele Road, that led to various part of Benin City thrown into blackout and maximum load-shedding was inevitable in the system.

(g) Inadequate Training and Retraining of Technical Personnel: Engineering is a very dynamic field of profession; hence, it is necessary and compulsory for practicing engineers to always involved in constant and regular technical and non-technical training and retraining programmes. These training programmes are to equip the engineers with the new techniques trending in the field of their profession and to be able to face new challenges and constraints that may emerge in their respective fields and the know-how to tackle such challenges trending in the twenty first century but it is appalling to learn that there is a great apathy towards training and retraining for some time now in the industry (Awosope, 2014).

(h) Inadequate Funding: Because the TCN is solely funded by the federal government whose resources allocation is limited and inadequate to meet all the needs of TCN as at today; hence, the system experienced a retardation in expansion and outdated grid 
with inadequate redundancies as opposed to the required mesh arrangement compared to other modernised grid in developed countries.

(i) Inability to Perform Real-Time Operations: This is the inability of the power transmission network of Nigeria to carry out various and critical real-time operation on the network as a result of lack of modern equipment and obsolete skills on the part of the man-power. The power systems challenges and constraints are dynamic and when the training and retraining of skilled man-power is relegated to the background all in the name of limited or lack of funds on the part of the government, the resultant effect is that outdated skilled man-power and equipment will keep on running the system. The result is archaic and outdated operations where skills to upgrade and operate new and modern equipment that would have better the transmission system of Nigeria will be lost out. This is the result of the deaf ears on the part of the Federal Government of Nigeria.

(j) Low Morale among Workers and Embargo on Employment: The Nigerian engineers are among the best in the world, but due to politics of appointing a political figure as the head of the engineering parasternal, they generally lose interest in the system (Ebewele, 2011). This is because the competent engineers have seen it as a way of relegating them and their contributions to the industry to the background. "This has dampened the engineers' enthusiasm at developing ingenious maintenance approach for effective and efficient running of the power industry. Most of these nonprofessionals do not appreciate the essence of engaging in routine maintenance and schedule maintenance. To further aggravate the situation, there has been an embargo on employment of fresh graduates into the industry. This portends a very dangerous signal in the sense that there is imminent crisis of generation gap being created by this kind of policy" (Awosope, 2014). This means that when older generation of engineers are retiring there would not be enough tested hands to take over from them.

(k) Ineffective System Reliability Management: Reliability management of the power transmission system as at today is very poor. The necessary detailed data needed to actually carry out effective management of the system reliability are yet available and the available once are outdated. Joskow (2006) stated that the transmission reliability criteria were mostly developed in the 1950s and have been carried-over essentially by the unchanged norms of the old regime of regulated vertically integrated monopolies. Consequently, "these reliability criteria characterised by more decentralised decision makers, more uncertainty and variability, and more interconnected network."

(I) Inadequate Coverage of Transmission Infrastructure: It is assumed today that the wheeling capacity of $5400 \mathrm{MW}$ with respect to the Nigeria current estimated population of about one hundred and eighty million $(180,000,000)$ people (PWC, 2016) is seriously inadequate considering the energy per capita. PWC (2016) stated that "the evacuation capacity of the transmission network of Nigeria which currently stands at 5400MW is a major shortcoming that is aggravated by inadequate funding of the TCN and triggered by its low operating tariff, uncompleted legacy of projects and declining budgetary allocation. This clearly has shown that the energy per capita in Nigeria is still grossly low compared to other developed countries like USA etc. Based on the wheeling capacity of $5400 \mathrm{MW}$ and the estimated population currently, the energy per capita in Nigeria stands at about $0.03 \mathrm{~kW}$ which is a far cry from standard norms in other developed countries. As at today, the Nigeria transmission network is urbanised; in other word, the transmission network run through major cities and towns while the interior villages and some towns are yet to be connected to the network. The map of the existing national grid is shown in Figure 3, which clearly shows the weak coverage of the Nigeria transmission network.

(m) Global Trend towards Urbanisation: In recent time, the rural- urban migration in Nigeria have suddenly converted some residential areas into commercial centres thereby increasing the load of the existing power transmission network of the area. 
The overloading of transformers of the transmission and distribution networks are one of the major characteristics of the current Nigeria power systems.

(n) Lack of Funds: The transmission system of Nigeria before now is solely funded by the federal government of Nigeria with little or no assistance from anyone else, as it were before the unbundling of the power sector. Therefore, because there is inadequate funding from the sole source (Federal government of Nigeria), the power transmission company is unable to extend their services to some rural and urban sections of this country which has hindered the industrialisation of this nation as it where today, hence, the on-going building of new transmission line such as $986.5 \mathrm{~km}$ of $33 \mathrm{kV}$ lines and $705.3 \mathrm{~km}$ of $132 \mathrm{kV}$ under construction (Labo, 2010).

It often being said that the existing transmission infrastructure and its operation is the weakest link in the Nigeria electricity industry value chain. The transmission is responsible for many instances of stranded generation. Therefore, the improvement of its operational performance to the attainment of stable and reliable power supply to all Nigerians is a key to economic growth and development of the country.

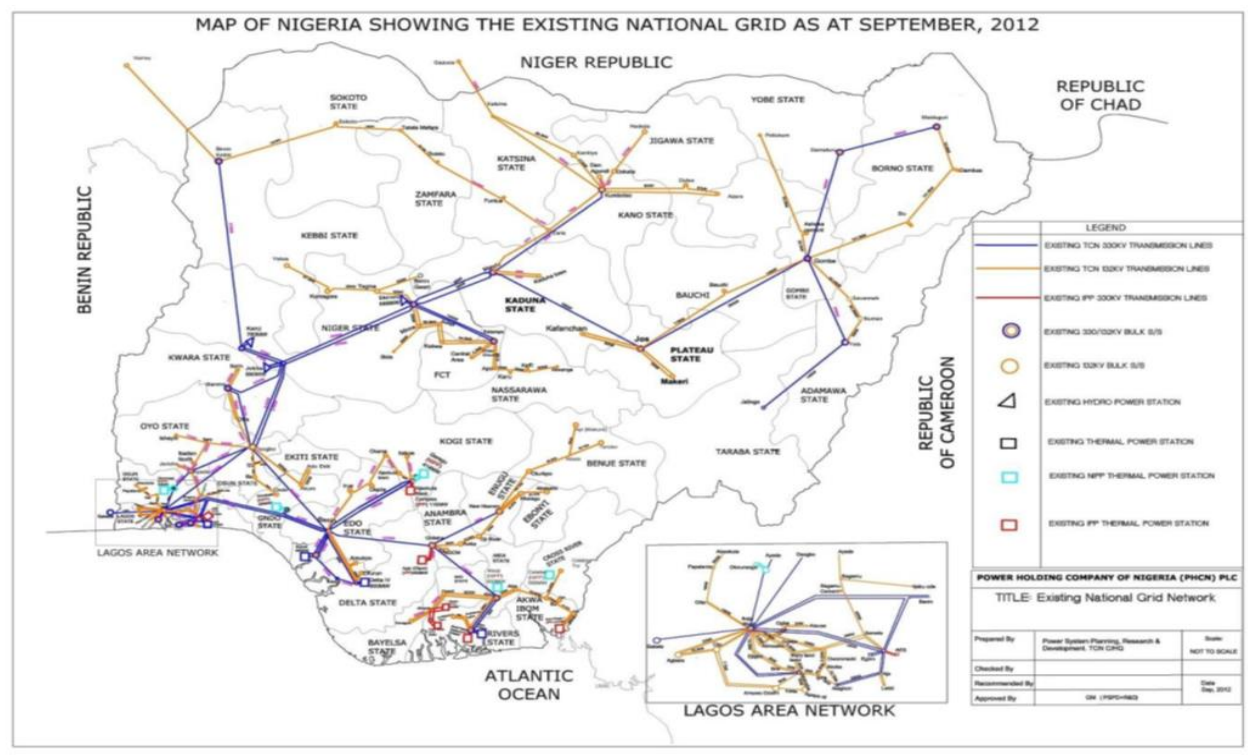

Figure 3. Map of Nigeria Showing Existing National Grid (Ohiare, 2014).

\section{Current State of the Nigeria Transmission Network Infrastructure}

The current state of transmission infrastructure can be itemised as follows: transmission capacity less than 6000MW; high non-technical and technical losses; low infrastructure coverage less than $40 \%$ of the country; and low per capita of generation is less than 25W (Labo, 2010). The existing TCN transmission line system and infrastructure of Nigeria transmission system are highlighted in Figure 4 and Table 1 complement it.

The ongoing transmission infrastructure include the $986.5 \mathrm{~km}$ of $330 \mathrm{kV}$ lines are under construction; the $705.3 \mathrm{~km}$ of $132 \mathrm{kV}$ lines under construction; the $1,350 \mathrm{MVA}$ capacity of $330 / 132 \mathrm{kV}$ transformer are presently being installed in new substations; the over loaded transmission stations are constantly being reinforced with additional capacity; and the 3,000 MVA capacity of $132 / 33 \mathrm{kV}$ transformers is currently being installed in new substations (Labo, 2010).

The National Integrated Power Project (NIPP) has also contributed to the development of the transmission system of Nigeria. The ongoing NIPP transmission projects have increased the: $330 \mathrm{kV}$ capacity by $5,590 \mathrm{MVA}$; $132 \mathrm{kV}$ capacity by $3,313 \mathrm{MVA}$; $330 \mathrm{kV}$ transmission line length by $2,194 \mathrm{~km} ; 132 \mathrm{kV}$ transmission line length by $809 \mathrm{~km}$; and have also increased the system by ten new 330kV substations and seven new $132 \mathrm{kV}$ substations; in addition to the expansion/reinforcement of 32 existing $330 \mathrm{kV}$ and $132 \mathrm{kV}$ substation. 


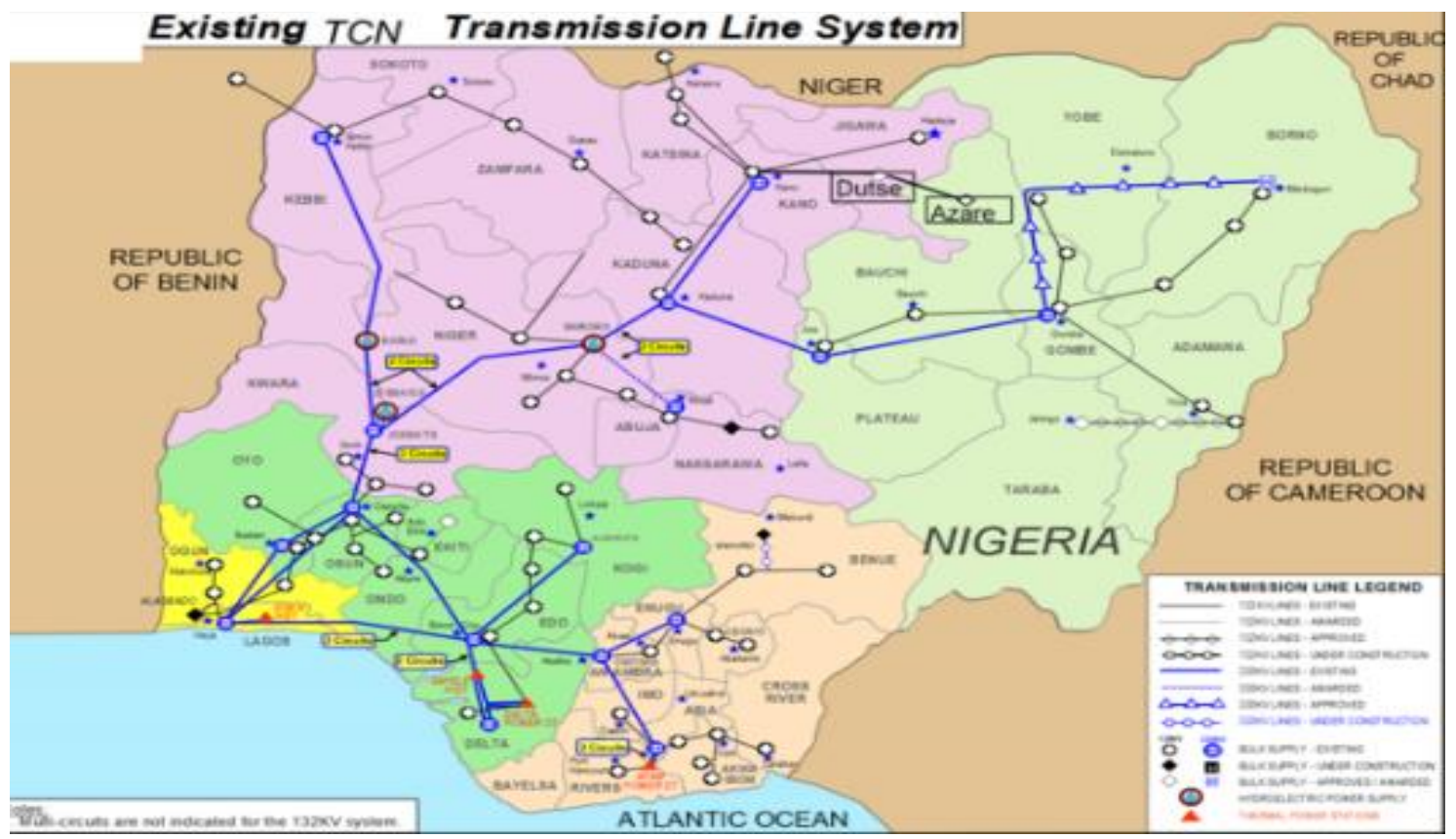

Figure 4. Existing TCN Transmission Line System

Table 1. Existing Transmission Network Infrastructure

\begin{tabular}{|c|c|}
\hline Description of Parameters & Rating/ Numbers of Equipment \\
\hline Transformation Capacity of 330/132kV & $7,044 \mathrm{MVA}$ \\
\hline Transformation Capacity of 132/33kV & $9,852 \mathrm{MVA}$ \\
\hline Numbers of 330kV Substations & 28 \\
\hline Numbers of 132kV Substations & 119 \\
\hline Numbers of 330kV Circuits & 150 \\
\hline Numbers of 132kV Circuits & $5,523.8 \mathrm{~km}$ \\
\hline 330kV Transmission Line Length & $6,801.49 \mathrm{~km}$ \\
\hline 132kV Transmission Line Length & 1 \\
\hline Number of National Control Centre & 1 \\
\hline Number of Supplementary National Control \\
Centre & 2 \\
\hline Numbers of Regional Control Centre & $2018)$ \\
\hline
\end{tabular}

Source: Modified (Ohiare, 2014; Ajenikoko et al., 2018).

\section{Assessment of Nigeria Rural Electrification Scheme}

Rural electrification challenge is global, especially in the developing countries like ours. The problems of rural electrification in Nigeria is acute and peculiar because the country has not been able to provide adequate supply to the connected populace let alone the rural areas of the country. Moreover, it has not been able to extend its service of transmission of power to all nook and cranny of the connected area of the country. This is due to various challenges that the electricity transmission company of Nigeria face with rural communities and financial obstacles.

The Rural Electrification Agency (REA) was established by section 88(1) of the Electric Power Sector Reform Act (EPSRA) 2005. Its mandate includes to (Rural Electrification Agency, 2014):

(a) promote Rural Electrification in Nigeria;

(b) provide rural electrification programmes in order to achieve more equitable regional access to electricity and promotion of expansion of the grid and development of offgrid electrification (KPMG, 2013); 
(c) co-ordinate Rural Electrification Programmes in Nigeria; and

(d) administer the Rural Electrification Fund (REF); to promote, support and provide electricity access to rural and semi-urban areas of Nigeria (KPMG, 2013) through public and private sector participation.

Since the inception of Nigeria Rural Electrification Scheme in 1981, its primary objective has been to increase electricity access to rural areas or communities all over the country. The strategy deployed then by the Nigeria Rural Electrification Scheme was to extend the Nigeria National Grid System (NNGS) to provide electricity to local government headquarters. Meanwhile, this has resulted in greater access to electricity by Local Governments and fortunate consumers in the immediate vicinity; though rural households have not seen much improvement in the availability of service (Anumaka, 2012). In fact, today, it is estimated that only about $20 \%$ of rural households have access to electricity as shown in Table 2, less than when the Nigeria Rural Electrification Scheme (NRES) commenced in 1981. The growth in demand for electricity has outpaced its supply and population growth, this has driven the rate of new household formation higher than the rate of new connections. Consequently, rural households still rely on fuel-wood, candle and expensive, unhealthy and unsustainable sources of energy to light - up their environment as shown in Table 2 (Rural Electrification Agency, 2014).

Table 2. Type of Main Lighting Fuel by Regular Households in Percentage

\begin{tabular}{|c|c|c|c|c|c|c|c|c|}
\hline Areas & $\begin{array}{c}\text { Total } \\
\text { Firewood Used }\end{array}$ & Grass & Kerosene & Electricity & Gas & Battery & Candles & $\begin{array}{c}\text { Other } \\
\text { Means }\end{array}$ \\
\hline Urban & 4.1 & 0.4 & 32.8 & 57.2 & 0.2 & 3.6 & 0.4 & 1.2 \\
\hline Rural & 13.1 & 0.7 & 41.3 & 20.0 & 0.1 & 19.6 & 0.9 & 4.2 \\
\hline NGA & 9.6 & 0.6 & 38.0 & 34.7 & 0.1 & 13.3 & 0.7 & 3.0 \\
\hline
\end{tabular}

Source: Modified (Ohiare, 2014).

Figure 5 clearly shows the rate at which the rural areas and households in Nigeria still rely heavily on other means to light up their environment despite the Nigeria Rural Electrification Scheme (RES) established since 1981. The rate of consumption of fuelwood, candle, battery, electricity and other means of energy by rural households in Nigeria is still on the high side till now despite the establishment of RES. Figure 6 shows eight means of lighting rural and urban houses in Nigeria.

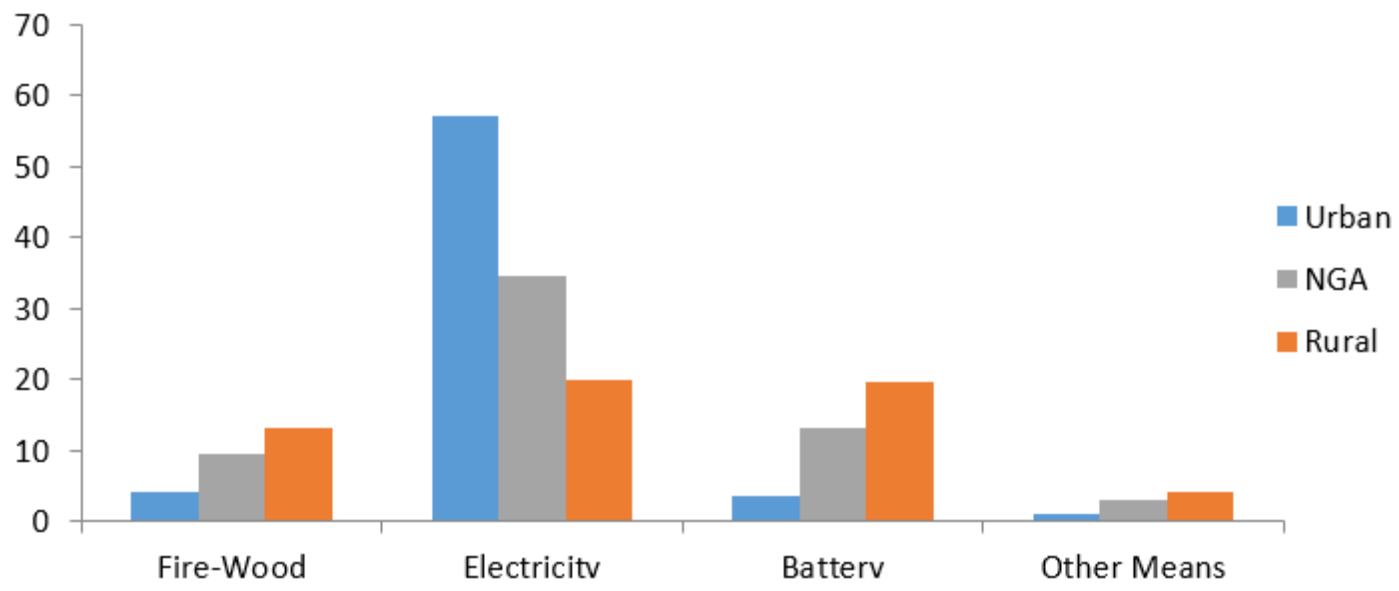

Figure 5. Means of Lighting up Rural Households in Nigeria.

Figure 6 clearly shows why the migration from the rural to urban area in Nigeria is very high today. It also shows that urban area consumption of gas and electricity is higher as a means of lighting up houses in Nigeria with about $0.2 \%$ and $57.2 \%$ respectively, while the rural areas have high consumption in firewood, grass, kerosene, battery, candle and other means ranging from $13.1 \%, 0.7 \%, 41.3 \%, 19.6 \%, 0.9 \%$ and $4.2 \%$ respectively. With the above comparative analysis, it is obvious that the rural areas consume high polluted means of lighting houses in Nigeria. This is as a result of the rural electrification 
scheme failure to meet the demand for electricity to the rural consumers in Nigeria and also the weakness of the Nigeria National Grid System to extend power supply to the rural areas of Nigeria especially Niger Delta Region.

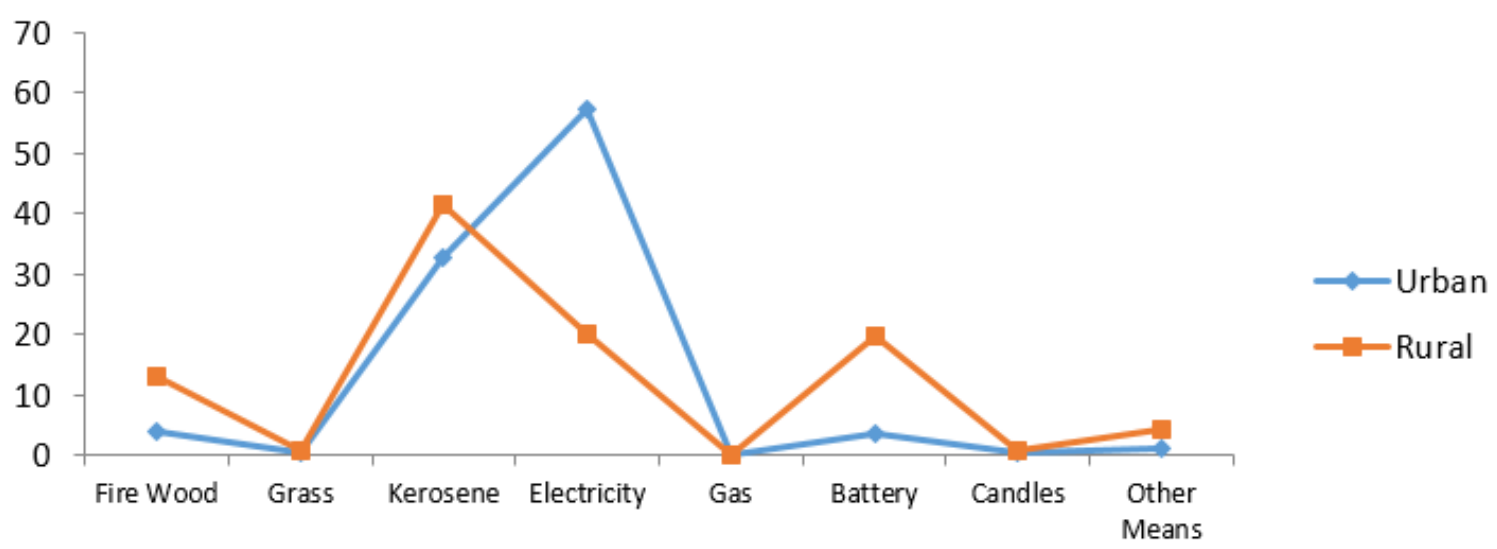

Figure 6. Means of Lighting up Urban and Rural Households in Nigeria

Table 3 and Figure 7 show the rate of rural electrification in different zone of Nigeria.

Table 3. Percentage of Electricity Supply in Different Zone of Nigeria

\begin{tabular}{|c|c|c|c|c|c|}
\hline Regions & $\begin{array}{c}\text { Defunct } \\
\text { PHCN }\end{array}$ & $\begin{array}{c}\text { Rural } \\
\text { Electrification }\end{array}$ & $\begin{array}{c}\text { Private } \\
\text { Generator }\end{array}$ & $\begin{array}{c}\text { Defunct } \\
\text { PHCN/Generator }\end{array}$ & $\begin{array}{c}\text { Rural } \\
\text { Electricity/Generator }\end{array}$ \\
\hline $\begin{array}{c}\text { North- } \\
\text { Central }\end{array}$ & 81.9 & 1.8 & 1.0 & 14.9 & 0.0 \\
\hline $\begin{array}{c}\text { North- } \\
\text { East }\end{array}$ & 82.3 & 9.8 & 1.6 & 5.9 & 0.5 \\
\hline $\begin{array}{c}\text { North- } \\
\text { West }\end{array}$ & 94.8 & 2.3 & 0.9 & 2.1 & 0.0 \\
\hline $\begin{array}{c}\text { South- } \\
\text { East }\end{array}$ & 90.8 & 2.8 & 0.9 & 3.5 & 0.4 \\
\hline $\begin{array}{c}\text { South- } \\
\text { South }\end{array}$ & 79.3 & 8.8 & 1.7 & 8.3 & 1.9 \\
\hline $\begin{array}{c}\text { South- } \\
\text { West }\end{array}$ & 83.9 & 0.3 & 5.2 & 10.5 & 0.1 \\
\hline
\end{tabular}

Source: Modified (Ohiare, 2014).

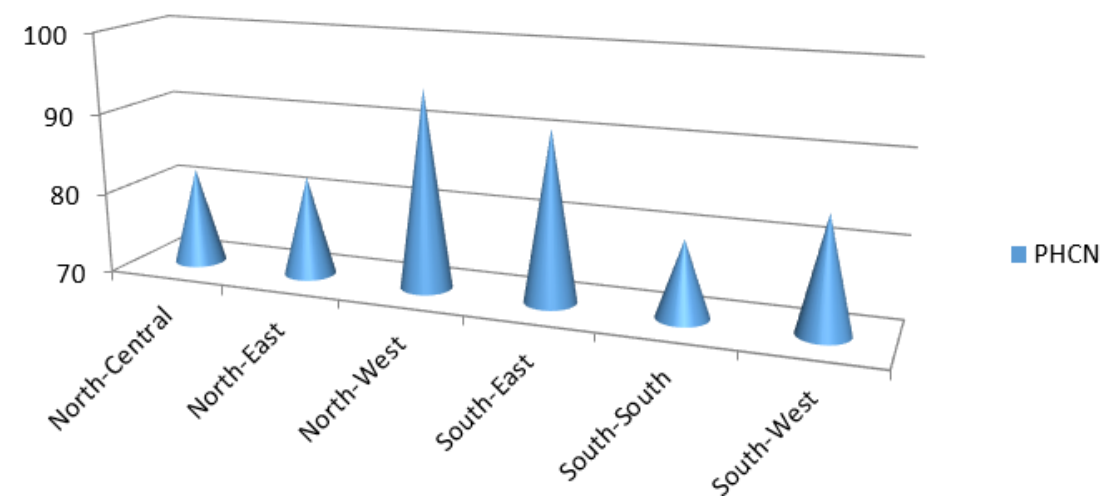

Figure 7. Percentage of Electricity Supply in Different Zone of Nigeria

The Figure 7 shows the percentage of electricity supply by the then Power Holding Company of Nigeria (PHCN). From the bar chart, South-South have the lowest electricity supply of about $79.3 \%$ followed by North-Central, North-East, South-West of $81.9 \%$, $82.3 \%$ and $83.9 \%$ respectively. The South-East and North-West have the highest electricity supply by the then PHCN of about $90.8 \%$ and $94.8 \%$ respectively. The lower electricity supply in the South-South is due to the following factors itemised in section 5 . 
The percentage of rural electrification in different zone of Nigeria can be clearly represented in Pie chart as shown in Figure 8.

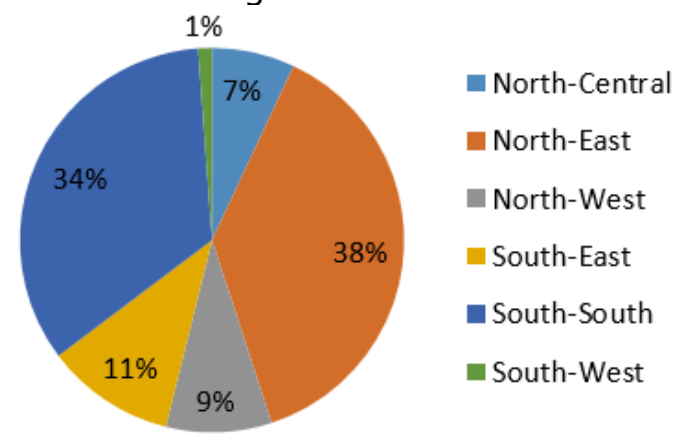

Figure 8. Rural Electrification in Different Zone of Nigeria

The Pie Chart clearly showed that the South-East zone has the highest percentage of rural electrification of $38 \%$, follow by the South-South zone of $34 \%$, South-East of $11 \%$, North-West of $9 \%$, North-Central of $7 \%$ and South-west of $1 \%$ in Nigeria Rural Electrification Scheme.

\section{Issues and Challenges of Nigeria Rural Electrification Scheme}

The Rural Electrification Scheme is aimed at promoting the welfare of the rural communities and also to improve the economic status of the people in the rural areas (Afa, 2013). In addition, the rural electrification also helps for industrialization of the rural areas and thereby leading to the development of the country and civilization of her citizens (Akpojedje et al., 2016). The issues and challenges of the rural electrification scheme in Nigeria today are enormous, ranging from technical, non-technical to political issues. Some of the common issues and challenges faced by the Rural Electrification Scheme in Nigeria are highlighted below as follows:

(a)Topography of the Niger Delta Region: The geographical position of the Niger Delta Region has posed various challenges to rural electrification and transmission of electrical power which is due to the swamping nature of the region. The region is bound by rivers, estuaries, creeks, stagnant swamps etc., that pose problems to rural electrification in terms of settlements and accessibility of roads, good available means of transport etc. (Afa, 2013). The climatic conditions and the flooding nature of the region are major factors militating against the rapid growth of rural electrification of Nigeria. The lack of industrial customers, low load forecast, the terrain and swamping nature has necessitated a very long distance from the grid with huge cost of installation, maintenance and operation. These are the key factors that hamper the rural electrification transmission.

(b)Inadequate Funding: The rural electrification scheme has been poorly funded by the federal government of Nigeria. This is because the federal government is the sole organ that fund the system before the unbundling of the power sector with little or noassistance from non-governmental bodies. The monopoly of the power sector by the defunct NEPA and provision of funds by government alone did not help the drive for rural electrification (Ohiare, 2014). This has actually hindered the rural electrification scheme in Nigeria

(c) Militancy: The militancy that exist in the rural areas of Nigeria has pose allot of challenges to the growth of rural electrification in Nigeria. For example, the Niger Delta Militants which called themselves freedom fighters started many years ago with the Niger Delta agitation for a fairer distribution of oil revenue. The activities of this groups later turn to political and selfish gain with unrest in the Niger Delta Region which made many industries to close down and relocated. This unrest has caused high hindrance to the rural electrification scheme in Nigeria. 
(d)Policy Inconsistency and Legislative Constraints: The frequent changes in government have resulted in changes in programmes and policies, thereby leading to lack of continuity in policies and programmes (Diji, 2014). Yet the fact remains that the issue of sustainable access to energy and, in particular electricity, cannot be totally handled or achieved within the lifespan of one government (tenure). Furthermore, the extension of energy to remote rural areas require huge capital both human and financial, which might be above what a single government budget could support. Consequently, policy inconsistency often linked to changes in government and it remains one of the greatest hurdles militating against the achievement of affordable and sustainable energy in Nigeria.

(e)Crisis, Conflict and Insecurity: Crisis, conflict and insecurity in various region of the country pose serious challenge to the rural electrification scheme especially the unrest in the Niger Delta region caused by militancy and the North-East region caused by Boko Haram activities hinder the success of the effective provision of affordable and sustainable energy to the interior rural areas of the country.

(f) Policy Somersault: The Nigeria power sector has suffered from policy somersault because of one administration after another identifies the sector as key to economic growth and development of the nation. However, in trying to address this, they often continue with entirely new policies instead of them continuing with that of the previous administration (Onochie et al., 2015). This failure of policy continuity has posed a lot of hindrance to the rural electrification growth and development.

(g)Poor Technical Staff: The rural electrification scheme of Nigeria has faced a lot of poor technical staff in terms of recruitment, capacity building and training program. Most of the staff are not properly trained and the training program set up by the federal government is frowned by situation in the power sector industries. Staff are selected on the basis of 'who you know' and connections with the man at the helm of affairs. This situation has necessitated poor performance of the staff and the growth of the rural electrification. This has also caused low staff morale and lack of regular training.

(h)Data Inadequacy: There is no adequate data for correct estimation of the rural customers for planning. This greatly accounts for the uneven allocation and distribution of rural electrification system to the rural region (Onochie et al., 2015). This has actually affected the decision making of the rural electrification scheme to maximise their efficiency and output.

(i) Political Issues: Due to the dynamic nature and geopolitical division of Nigeria, government of the day tends to favour her geopolitical zone with policies and funds distribution. This has led to constant policing changing in the system with uneven distribution of resources. The rural electrification schemes face these policies changing constantly which hindered the rural electrification process in Nigeria.

(j) Affordability: The ability of the interior rural areas of the country consumers to pay for improved energy services is a major issue because majority of the rural consumers are predominantly engaged in peasant agriculture and allied and, their income streams are often seasonal, low and not steady throughout the year (Diji, 2014). Consequently, the enthusiasm of the energy provider is grossly low in terms of morale to rural electrification.

(k)Corruption: The level of corruption in the Nigeria governmental system has pose serious challenge to the success of government on power project in the rural communities of Nigeria. In other words, the Rural Electrification Scheme of Nigeria has serious drawback due to high level of corruption on the government official. Most projects are awarded close to election period just to get votes of Nigerians or for the purpose of electioneering campaign during election. Elusakin et al. (2014) stated that the 2006/2007 rural electrification project corruption saga is still fresh where about 1,946 projects were neglected.

The Nigeria transmission network issues and Rural Electrification Scheme challenges can be summarised as radial lines with no redundancies; obsolete substation equipment;

$$
\text { I S N : } 2636-607 X
$$


overloaded transmission lines and substations; inadequate coverage of infrastructure; limited funds for developments projects; high technical and non-technical losses; limited training opportunity; community issue during project execution; swamping nature of most rural areas; inadequate maintenance procedure for infrastructure; political issues; corruption; and militancy (Labo, 2010).

\section{The Way Forward}

The way forward to remedy the Nigeria transmission network and rural electrification scheme issues, challenges and constraints are as itemised:

(a) Expansion of the Existing Network: The current transmission network cannot evacuate total power that would be generated if all the NIPPs and IPPs project fully come on stream. Therefore, there is need to expand the present transmission network to increase the wheeling capacity and meet current demand, and also, to ameliorate the present challenges. Therefore, the future plan for transmission network expansion (330kV and Super Grid Networks especially) for 2013 and beyond by the Federal Ministry of Power in 2013 should be implemented religiously as showed in Figure 9.

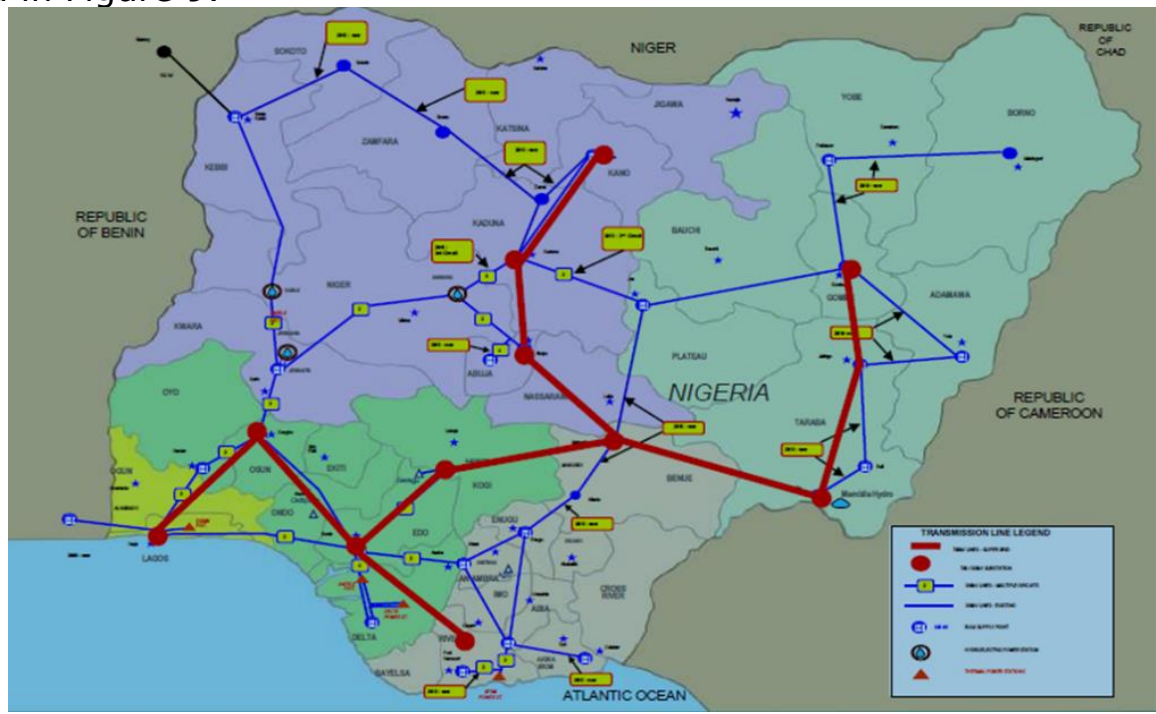

Figure 9. Future Plan for Transmission Expansion (330kV and Super Grid Networks) for 2013 and beyond (Federal Ministry of Power, 2013)

(b) Introduction of More Loops: The radial, fragile and long transmission lines must be re-structured to introduce more rings or meshes into the network.

(c) Introduction of Super Grid: Introducing Super Grid (SG) in the Nigerian National Grid (NNG) will enhance the wheeling capacity limitations currently and also minimized the high power losses being experienced in the network. "Super grid is a transmission system with a much higher voltage. The super grid in America transmits at $750 \mathrm{kV}$ (Adekilekun et al., 2018). Furthermore, the authors opined that it is easily understood that super grids offer a better advantage over what Nigerian transmission system presently has and the construction of super grid will solve the problems of transmission lines high power losses in the network.

(d) Grid Extension: Extension of the Nigeria National Grid System to serve additional rural communities in the 36 states of the federation will be one of the best options to solve the rural electrification challenges in Nigeria. The extension should be done with consultation with the Nigeria Transmission Company and Distribution Companies of Nigeria (Labo, 2010).

(e) Reduction of Power Losses: The enormous power losses associated with the transmission network must be vigorously tackled. Deploying FACTS and other compensating devices instead of the present sluggish and mechanically controlled 
devices on the transmission network would go a long way in addressing this problem as highlighted in this paper.

(f) Provision of Mini-Grid Systems: There should be provision of mini-grid system in the remote areas of the rural communities where the national grid cannot be extended to; the mini-grid system will be effective and efficient option to electrify the rural communities. The Nigeria government should adopt the mini-grid system to reach the rural communities with difficult terrain.

(g) Contingency Analysis Study: The power sector operators must also take into cognisance the unstable nature of the network and conduct contingency analysis study to strengthen the network to withstand contingencies and improve transmission capability thus minimising outages.

(h) Upgrading of Transformers: Overloaded transformers of the transmission network should be upgraded especially during expansion of load. Also, if transformers overloaded are not upgraded, it can lead to transformer breakdown, like the case of two 60MVA in the Benin transmission Company of Nigeria (TCN) station, Benin Zone that got broken down and threw major parts of Benin City and its environs into blackout for several weeks in the year 2018.

(i) Promulgating Proactive Technical Policy: Policies that are technically inclined should be proactively promulgated by policy maker in the country. Stakeholders should make policies that will drive the technological sector and jettison any policy that will hinder the technical and non-technical development of the Nigeria power transmission network (Akpojedje et al., 2017).

(j) Continuity of Government Policies Implementation: The instability of Nigeria government in policy making and keeping (continuity) should be jettisoned in Nigeria governmental system. The issue of one government will promulgate policy and another one will step it down or make it redundant should be eliminated from the Nigeria system.

(k) Renewable Energy: With the presence of renewable energy sources such as wind, biomass, and solar, the Nigeria government should embark on off-grid electrification project and this could solve the problems of rural electrification challenges if properly harnessed.

\section{Conclusion}

The Nigeria's transmission segment of the power sector value chain is lagging behind. As it is today, very little investments have come in since the power sector reforms and various issues, challenges and constraints faced by Transmission Company of Nigeria (TCN) and this will continue to hinder the realisation of a reliable and stable power supply envisaged by the reforms from onset. Consequently, it is important that the power TCN addresses the current problems in the management and operation of transmission system. Since the major issues, challenges and constraints itemised in this paper are now widely understood, the TCN should move beyond conflicts over power reforms and address the current transmission issues, challenges and constraints facing the Nigeria power sector especially the wheeling capacity of the network. There is need to continue making steady progress and through collaboration process in resolving the more pressing and serious issues and challenges affecting the efficiency and growth of the transmission network as quick as possible.

A body should be set-up that monitors and evaluate the activities and progress of the TCN so that we can achieve better characteristics of a well-functioning power transmission network. The Nigeria transmission network is considered to be very weak due to ageing network and few routes available to evacuate power generated (wheeling capacity). Hence, upgrading the network and the training and retraining of staff with current technology is a veritable tool to the development of the transmission network in Nigeria. While the low population density, low consumption and difficult terrain are the major causes of the challenges and issues of the rural electrification scheme in Nigeria today, the rural region of Nigeria suffers for electricity or power supply from the power sector in

$$
\text { I S N : } 2636-607 X
$$


Nigeria. Consequently, no small or medium scale industries are attracted to the rural areas, which is the cause of rural-urban migration been witnessed in Nigeria today.

The provision of electricity in the rural areas should be encouraged by all levels of government and communities' leaders. The lengthy distance of the transmission system used in evacuating electric energy to consumers resulted to greater electricity (power) loss that requires more expensive customer support and equipment maintenance, but the rural customers are poor with very low and unsteady income. It could be seen that even if a tariff system is introduced, the rural electrification scheme will need a highly subsidised government support or some agency to properly deliver the required services. Hence, the rural electrification is not attractive and cannot attract competitors. Due to the terrain and the challenges of transporting power to the rural areas; an off-grid service based should be properly studied and implemented in these areas. This will increase and improve the availability of electricity to the rural areas of Nigeria with extremely bad topography.

\section{Conflict of Interests}

The authors declare that there is no conflict of interests regarding the publication of this paper.

\section{References}

Adekilekun, T. M., Raji, M. A., Sanusi, M. A., Bamikefa, I. A., \& Ayoade, M. A. (2018). Nigerian transmission system constraints and solutions, International Conference of Science, Engineering \& Environmental Technology, 3(5): $30-35$.

Afa, J. T. (2013). Problem of rural electrification in Bayelsa state, American Journal of scientific and Industrial Research, 412, 214.

Ajenikoko, G. A., Eboda, W. A., Adigun, O., Olayinka, A., Oni, S. O., \& Adelowo, L. (2018), Analysis of power sector performance: Nigeria as a case study, Mathematical Theory and Modelling, 8(8): $64-71$.

Akpojedje, F. O., Abu, Y. O., \& Onogbotsere, M. E (2017). Engineering and technology: a stimulating transformer for national development, An International Journal of Advanced Computer technology, 6(1): $2260-2268$.

Akpojedje, F. O., Onogbotsere, M.E., Mormah, E.C., \& Onogbostere, P. E. (2016). A comprehensive review of Nigeria electric power transmission issues and rural electrification challenges, International Journal of Engineering Trends and Technology, 31(1): 1 - 9.

Anumaka, M. C. (2012). Analysis of technical losses in electrical power system (Nigerian $330 \mathrm{kV}$ network as a case study), International Journal of Research and Review in applied Science, 12(2): 320.

Awosope, C. A. (2014). Nigeria electricity industry: issues, challenges and solutions, Covenant University 38Th Public Lecture Series, 3(2): 1 - 40.

Diji, C. J. (2014). A critical assessment of the Nigerian rural electrification policy, Mechanical Engineering Department, University of Ibadan, Ibadan, Nigeria. Retrieved from http://www.internationalpolicybrief.org/images/journals/Engr/Journal\%20Engr\%20and\%20sci ence13pdf (December 11, 2018).

Ebewele, I. O. (2011). Electricity sector reform and the challenges of power generation in Nigeria, Paper Presented at the Summit on Energy and Sustainable Economic Growth, Energy Commission of Nigeria organised Workshop at Ladi Kwali Hall, Sheraton Hotel and Towers, Abuja, 9th - 10th March.

Edet, O. A., \& Boniface, A. (2016). Power sector reforms and electricity supply growth in Nigeria, Asian Journal of Economics and Empirical Research, 3(1): 94 - 102.

Ekeh, J. C. (2003). Electric power principles, Amfitop Books a subsidiary of Amfitop Nigeria limited, First Edition, $213-223$.

Elusaki, J. E., Ajide, O. O., \& Diji, J. C. (2014). Challenges of sustaining off-grid power generation in Nigeria rural communities, African Journal of Engineering Research, 2(2): 55. 
Federal Ministry of Power (2013). Introduction - ministry of power, works and housing, Retrieved from http://www.power.gov.ng/download/Overview\%20of\%20Nigeria's\%20Power\%20Sector.pdf (December 11, 2018)

Isola, W. A. (2012). An analysis of electricity market structure and its implications for energy sector reforms and management in Nigeria, the Department of Economics, Faculty of Social Sciences, University of Nigeria, Nsukka, $1-69$.

Iwuamadi, O. C., Dike, D. O., \& Iwuchukwu, U. C. (2014). Nigerian power sector: comparative analysis of productivity, American Journal Engineering Research, 3(6): 8 - 14.

Joskow, P. L. (2006). Patterns of transmission investment, Competitive Electricity Markets and Sustainability, Francois Leveque, (ed.), Edward Elgar, 2006, 169 - 235.

Kalu, U. (2018). Deregulation of the Nigerian power sector on performance: a review, European Journal of Scientific Research, 148(3): 377 - 385.

KPMG (2013). A guide to the Nigerian power sector, KPMG in Nigeria, $1-48$. Retrieved from http://www.kpmg.com/Africa/en/IssuesAndInsights/Articles-Publications/Pages/NigerianPower-Sector.asp (December 11, 2018)

Labo, H. S. (2010). Current status and future outlook of the transmission network, Investors' Forum for the privatisation of PHCN Successor Companies, 18 -19th of January.

Odiah, R. I. (2011). Challenges surrounding power investment in Nigeria: insights and perspectives from owners and developers, Paper Presented at the Summit on Energy and Sustainable Economic Growth, Energy Commission of Nigeria organised Workshop at Ladi Kwali Hall, Sheraton Hotel and Towers, Abuja, 9th - 10th March.

Ogbogu, N. O., \& Anaemeje, G. (2011). Electric power transmission optimization, JORIND, 9(1): 1 -9 .

Ogunleye, E. K. (2016). Political economy of Nigerian power sector reform, WIDER Working Paper, $9,1-31$.

Ohiare, S. M. (2014). Financing rural energy projects in developing countries: a case study of Nigeria,' PhD Thesis, De Montfort University, Leicester, United Kingdom (UK).

Ohohaebi, S. O. (2009). Power outages in the Nigeria transmission grid, Research Journal of Applied Sciences, 4(1): $1-9$.

Okoro, O. I., \& Chikuni, E. (2007). Power sector reforms in Nigeria: opportunities and challenges, Journal of Energy in Southern Africa, 18(3): 52 -53.

Ologundudu, M. M. (2015). The impact of electricity supply on industrial and economic performance in Nigeria, International Global Journal of Management and Business research, 2(4): 9 - 28.

Onakoya, A. B. (2013). Energy consumption and Nigerian economic growth: an empirical analysis, European Scientific Journal, 9(4): $25-40$.

Onochie, U. P., Egware, H. O., \& Eyakwanor, T. O. (2015). The Nigeria electric power sector (opportunities and challenges), Journal of Multidisciplinary Engineering science and Technology, 2(4): 4.

Onyi-Ogelle, H. O. (2016). The implications of legal reform in the Nigeria power sector, African Research Review: An International Multi-Disciplinary Journal, Ethiopia. 10(3:42): 279 - 289.

Oyedepo, S. O. (2012). Energy and sustainable development in Nigeria: the way forward, Sustainability and Society, 2(15): $1-17$.

Patrick D. R., \& Fardo, S. W. (2009). Electrical distribution systems, Second Edition, The Fairmont Press, Inc., Georgia, United States

PWC (Price Waterhouse Coopers Limited) (2016). The challenges with transforming the Nigerian power landscape, PWC'S Annual Power and Utilities Roundtable.

Rapu, C. S., Adenuga, A. O., Kanya, W. J., Abeng, M. O., Golit, P. D., Hilili, M. J., Uba, I. A., \& Ochu, E. R. (2014). Analysis of energy market conditions in Nigeria, Central Bank of Nigeria, Occasional Paper, 55, $1-80$.

Rural Electrification Agency (2014). New national rural electrification implementation strategy and plan. Retrieved from https://www.africanpowerform.org/resource/reports/westafrica/Nigeria/384-new-national-rural-electrification-implementation-strategy-and-plan.html (December 11, 2018) 
Sambo, A. S., Garba, B., Zarma, I. H., \& Gaji, M. M. (2010). Electricity generation and the present challenges in the Nigeria power sector, Energy Commission of Nigeria, Abuja- Nigeria, ResearchGate, Retrieved from https://researchgate.net (December 11, 2018)

Samuel, F., \& Sunday, S. E. (2019). Special report: despite huge investment in power, Nigeria suffered 206 grid collapses in 9 years, Premium Time Special Publication on Nigerian Democracy @ 20 https://www.premiumtimesng.com/investigationspecial-reports/358531-special-reportdespite-huge-investment-in-power-nigeria-suffered-206-grid-collapses-in-9-years.html

Samuel, I., Katende, J., Daramola, A., \& Awelewa, A. (2014). Review of system collapse incidences on the $330 \mathrm{kV}$ Nigerian national grid, International Journal of Engineering Science Invention, 31(4): 55 - 59.

Ugwoke, T. I., Dike, C. K., \& Elekwa, P. O. (2016). Electricity consumption and industrial production in Nigeria, Journal of Policy and Development Studies, 10(2): 8 - 19.

Wara, S. T., Abeyomi-Alli, A., Umo, N. D., Oghogho, I., \& Odikayor, C. D. (2009). An impact assessment of the Nigerian power sector reforms, Advanced Materials Research, 62(64): 147 152.

Yusuf, S. A. (2014). Energy sector is critical to Nigeria growth and development: perspective to electricity sub-sector in Nigeria, Munich Personal RePEC Archive, 55689; 1 - 30 